\title{
УДК: 342.95
}

DOI: 10.15587/2523-4153.2018.135841

\section{ЗАРУБІЖНИЙ ДОСВІД ПРАВОВОГО РЕГУЛЮВАННЯ АДМІНІСТРАТИВНИХ ПОСЛУГ У СФЕРІ ЕКОЛОГІЇ ТА ПРИРОДНИХ РЕСУРСІВ}

\author{
(C) К. С. Кучма
}

Наукове дослідження присвячене висвітленню зарубіжного досвіду надання адміністративних послуг у сфері екології та використання природних ресурсів та шляхи імплементації в вітчизняне законодавство України. Висвітлюється законодавство Казахстану, Франиії, США, Великобританії щуодо надання адміністративних послуг у сфері екологї та використання природних ресурсів. Визначено доцільність розроблення та впровадження загального екологічного дозволу, який діє на території краӥн Свропейського Союзу, щзо сприятиме забезпеченню комплексного використання природних ресурсів.

Встановлено, щзо право природокористування в зарубіжних краӥнах виникає в порядку надання адміністративних послуг (отримання дозволу, ліцензї, свідоцтва тощо) або у порядку укладення адміністративних договорів (як правило, на підставі результатів проведеного конкурсу). До першої групи віднесено такі зарубіжні країни, як Республіку Білорусь, Республіку Молдова, Російську Федерачію. До другої групи зарубіжних країн віднесено Республіку Казахстан, Республіку Киргизстан, Федеративну Республіку Німеччину у частині регулювання порядку надання ділянки надр у користування.

Доведено, щуо конкурсний порядок укладення адміністративних договорів на геологічне вивчення надр та (або) видобування корисних копалин дозволяє уникнути суб'єктивного фактору при розподілі природних ресурсів загальнодержавного значення за умови дотримання принципів прозорості та відкритості проведення відповідних адміністративних прочедур. Обтрунтовано доцільність впровадження досвіду Республіки Казахстан, щчо передбачає можливість застосування залежно від конкретних операцій з природокористування комбінованих договорів (контрактів), при цьому порядок укладання таких контрактів та їх зміст визначається законодавством.

Визначено успішність результатів проектів централізації системи надання адміністративних послуг у сфері використання земельних ресурсів шляхом створення централізованих реєстрів обліку земельних ресурсів в Королівстві Данія і Королівстві Швеція. Встановлено, щзо загальною світовою тенденцією, що характерно і для України, є об'єднання функиій адміністрування у сфері екології та природних ресурсів, щзо, зокрема, виражається у поєднанні реєстрації речових прав на земельну ділянку та картографічної діяльності, обліку лісових та земельних ресурсів тощо.

Визначено, щя в системі надання адміністративних послуг у сфері природних ресурсів в країнах Західної Європи (наприклад, у Королівстві Данія, у Королівстві Швеція та ін.) спостерігається ситуація переходу від децентралізованої моделі ведення державних реєстрів, зокрема иляхом створення єдиної иентралізованої системи обліку земельних ресурсів, щзо обумовлено передусім необхідністю інформатизацї реєстрів та забезпечення загальнодержавного доступу громадян до таких реєстрів, щяо можливо забезпечити лише в умовах державного ичентралізованого підходу

Ключові слова: адміністративна послуга, дозвіл, імплементачія, послуга, природні ресурси, екологія

\section{1. Вступ}

У сучасних умовах розвинені країни світу поряд 3 обранням демократичної форми політичного ладу, впровадженням і досягненням високих стандартів соціального захисту населення проголошують та вживають заходи 3 реалізації міжнародної політики забезпечення ефективного виробництва, зорієнтованого на збереження еколого-ресурсної бази й створення оптимальної моделі адміністративної системи у сфері охорони навколишнього природного середовища.

Вітчизняний досвід організації системи суб'єктів публічного адміністрування у сфері надання адміністративних послуг, зокрема й у сфері екології та природних ресурсів, свідчить про ефективність вивчення досвіду зарубіжних країн для оптимізації такої діяльності.

\section{2. Літературний огляд}

Наука порівняльного правознавства, незважаючи на ii очевидну актуальність у сучасних умо- вах розвитку юридичної науки загалом, поки що перебуває на стадії формування. Характеристика досліджень і публікацій сучасних авторів (Г. І. Балюк, В. М. Бевзенка, А. Г. Бобкової, А. П. Гетьмана, Т. М. Кравцової, О. С. Шемякова, О. О. Плотникової та інших згідно з результатами аналізу стану наукової розробки проблеми, проведеної в підрозділі 1.1 дисертації), присвячених проблемам природокористування, також свідчить про те, що порівняльному аналізу сучасного екологічного законодавства в зарубіжних країнах не приділялося достатньої уваги. Однак можна виділити розвідки I. В. Хохлової та О. П. Шем'якова [1, с.199-205], О. В. Леонової [2, с. 77-85], Р. М. Панаса й М. С. Маланчука [3, c. 68-75] та інших авторів, у яких встановлювались особливості адміністрування у сфері надрокористування, землекористування в зарубіжних країнах, проте комплексне вивчення іноземного досвіду надання адміністративних послуг у сфері екології й природних ресурсів не проводилось, що підтверджує його актуальність. 
Проте питання вивчення зарубіжного досвіду щодо надання адміністративних послуг у сфері екології та природних ресурсів вітчизняними вченими вивчалося не достатньо. Однак при цьому досвід правового регулювання адміністративних послуг у сфері екології та використання природних ресурсів країн Європейського Союзу, Сполучених Штатів Америки, враховуючи рівень його ефективності, має бути запозичено і враховано у процесі реформування системи публічного управління в цілому, і зокрема, у сфері використання природних ресурсів.

\section{3. Мета та задачі дослідження}

Мета статті полягає в тому, щоб на підставі комплексної характеристики особливостей нормативно-правового регулювання надання адміністративних послуг у сфері екології та природних ресурсів у зарубіжних країнах визначити можливість його впровадження до чинного законодавства України. задачі:

Для досягнення мети були поставлені наступні

1) визначити особливості правового регулювання надання адміністративних послуг у сфері екології та природних ресурсів в зарубіжних країнах;

2) встановити шляхи впровадження позитивного зарубіжного досвіду у сфері екології та використання природних ресурсів до чинного законодавства України.

4. Генезис правового регулювання зарубіжного досвіду щодо надання адміністративних послуг у сфері екології та природних ресурсів

Право природокористування, як правило, базується на наявності правовстановлюючих документів (свідоцтв, дозволів, ліцензій, відводів, довідок тощо), які підлягають державній реєстрації. У сфері використання природних ресурсів існує практика ведення держаних кадастрів. Запровадження кадастрових і реєстраційних систем у європейських країнах, на відміну від України, розпочалося ще в XIX столітті. В Україні перші державні кадастри та порядок їх ведення запроваджено з прийняттям таких нормативно-правових актів, як Закон України «Про державний земельний кадастр» від 7 липня 2011 р. № 3613-VI, Постанова Кабінету Міністрів України «Про Державний фонд родовищ корисних копалин України» від 2 березня 1993 р. № 150, Постанова Кабінету Міністрів України «Про затвердження Порядку ведення державного водного кадастру» від 8 квітня 1996 р. № 413, Постанова Кабінету Міністрів України «Про затвердження Порядку ведення державного лісового кадастру та обліку лісів» від 20 червня 2007 р. № 848 тощо. До основних джерел міжнародного права, які регулюють відносини природокористування, належать Резолюція Генеральної Асамблеї Організації Об'єднаних Націй «Право вільної експлуатації природничих багатств та ресурсів» від 21 грудня 1952 р. № 626, Резолюція Генеральної Асамблеї Організації Об'єднаних Націй «Постійний суверенітет над природними ресурсами» від 14 грудня 1962 р. № 1803, Конвенція Організації Об'єднаних Націй із морського права 1982 р. тощо.
У цілому, якщо охарактеризувати порядок надання адміністративних послуг у сфері використання природних ресурсів, зокрема й надання дозволів на спеціальне використання надр, то в країнах Співдружності Незалежних Держав спостерігається ситуація збереження моделі юридичної процедури, що існувала за часів адміністративно-командної системи.

Однак із загального правила є позитивні винятки. Таким є досвід організації надання адміністративних послуг у сфері надрокористування в Республіці Казахстан. Адміністративні послуги у сфері надрокористування надаються у вигляді ліцензії, що надається за результатами конкурсу інвестиційних програм, адміністративного акта уповноваженого органу з користування й охорони надр, ліцензії, що надається обласним виконавчим органом, а також контракту. Ліцензію на право розвідки та/або видобування корисних копалин у Республіці Казахстан надрокористувач отримує на підставі конкурсу інвестиційних програм або переговорів. Такий порядок надання адміністративних послуг у сфері надрокористування, впроваджений у Республіці Казахстан, за своєю сутністю $€$ унікальним і не застосовується в жодній іншій країні Співдружності Незалежних Держав, у тому числі в Україні. Ліцензія на розвідку та/або видобування видається одночасно з геологічним та/або гірничим відводом, що також суттєво зменшує час на отримання надр у користування, а відтак свідчить про доступність адміністративної послуги. Ліцензія на розвідку та/або видобування корисних копалин, геологічний та/або гірничий відводи $є$ підставою для укладення контракту на використання надр у Республіці Казахстан. Власне, геологічний відвід прямо нормами законодавства визначається як невід'ємний додаток до контракту на розвідку, видобування, поєднане з розвідкою, який схематично й дескриптивно визначає ділянку надр, на якій надрокористувач має право проводити розвідку (пункт 9 статті 1 Закону Республіки Казахстан «Про надра та надрокористування») [4].

При цьому аналіз норм законодавства про надра Республіки Казахстан дає змогу зробити висновок про адміністративно-правовий характер контракту на надрокористування. Про це свідчить положення пункту 38 статті 1 Закону Республіки Казахстан «Про надра та надрокористування», яке визначає контракт як «договір між компетентним органом чи уповноваженим органом із вивчення та/або використання надр або місцевим виконавчим органом області, міста республіканського значення, столиці відповідно до компетенції, встановленої законодавством Республіки Казахстан, і фізичною та/або юридичною особою на проведення розвідки, видобування корисних копалин чи будівництво та/або експлуатацію підземних споруд, не пов'язаних із розвідкою та/або видобуванням, або на державне геологічне вивчення надр» [4]. Ю. П. Битяк наголошує: «Адміністративний договір посідає проміжне місце між адміністративним актом (одностороннє волевиявлення державного органу влади) і договором приватноправового характеру» [5]. Адміністративні договори у сфері екології й природних ресурсів укладаються на підставі проведення 
конкурсу, за результатами якого підписується контракт, який підлягає державній реєстрації. У разі ненадання переможцем конкурсу проекту контракту на проведення операцій із надрокористування впродовж 7 місяців із дня винесення рішення про визнання переможцем конкурсу конкурсна комісія скасовує раніше ухвалене рішення про визнання заявника на отримання права надрокористування переможцем конкурсу. За умови надання переможцем конкурсу проекту контракту в зазначений строк він проходить відповідну експертизу й узгодження 3 державними органами. Компетентний орган на підставі позитивних висновків державних органів та обговорення умов контракту укладає контракт із переможцем конкурсу. У разі неукладення контракту впродовж 18 місяців із дня визначення переможця конкурсу за цим об'єктом конкурсна комісія скасовує раніше ухвалене рішення про визнання заявника на отримання права надрокористування переможцем конкурсу [4].

Крім того, варто зазначити, що за законодавством провідних зарубіжних країн однією $з$ тенденцій надрокористування $є$ активне залучення іноземних інвестицій, однак при цьому не втрачаються важелі національного державницького контролю й нагляду за діяльністю таких суб'єктів господарювання. Наприклад, у Норвегії необхідно заснувати дочірню компанію, забезпечення виконання зобов'язань якої контролюється державою, для отримання ліцензії на видобуток нафти на континентальному шельфі. Так само вимагається створення юридичної особи у Швеції для розробки корисних копалин на іiі теритоpiї. Натомість в Австралії видобуток корисних копалин здійснюють транснаціональні корпорації «Rіо Tinto», «BHP Billiton», діяльність яких не може прямо контролюватись державою, а лише через встановлення законодавчих норм і принципів екологічної й соціальної політики. У Китайській Народній Республіці реформою 1979 р. вдалося створити сприятливі умови для залучення іноземних інвестицій у національну економіку, у тому числі в нафтогазову промисловість, зокрема й на видобування корисних копалин у континентальному шельфі, що дало змогу збільшити обсяг видобутку нафти та поступово сприяло росту власних національних видобувних підприємств, які стали самостійними учасниками освоєння нафтогазових родовищ в інших країнах, таких як Алжир, Індонезія, Казахстан, Перу. Цей досвід співпраці 3 транснаціональними корпораціями має бути врахований також урядом України [6].

При цьому найголовнішою проблемою діяльності транснаціональних компаній у сфері використання природних ресурсів $\epsilon$ не лише проблеми економічного (зокрема, проходження суми оподаткування діяльності компаній повз державний бюджет України) та екологічного характеру (інтенсивний характер підприємств із надрокористування), а й відсутність законодавчої бази, що є підставою для правового регулювання діяльності таких компаній. Досі в Україні єдиним нормативним актом, який визначає діяльність транснаціональних корпорацій, є Конвенція про транснаціональні корпорації, ратифікована Верховною Радою України в 1999 р. із застереженнями [7]. Тому вимагається розробка та прийняття не лише декларативного акта, яким фактично $є$ ця конвенція, а й спеціального законодавчого акта, що визначить механізм реєстрації, правовий статус, правоздатність транснаціональних компаній; також вимагається ухвалення єдиного комплексного підходу до оподаткування результатів господарчої діяльності таких підприємств.

Якщо сфера надрокористування $\epsilon$, як правило, прерогативою переважно юридичних осіб, які саме $\epsilon$ споживачами відповідних адміністративних послуг, то споживачами адміністративних послуг у сфері використання земельних ресурсів є як фізичні особи, так і юридичні особи. Практика надання адміністративних послуг у сфері землекористування пов'язується 3 організацією ведення державних реєстрів.

У країнах Західної Європи (таких як Франція, Іспанія, Данія, Болгарія, Латвія, Литва) ведення державних реєстрів сягає ще XIX століття. У Франції зберігається наполеонівська адміністративна система, характерною особливістю якої є тісна взаємодія земельного кадастру та реєстру нерухомості. За ведення земельного кадастру й реєстру нерухомості відповідальне Міністерство національної економіки та фінансів Франції. При цьому відомості, що заносяться до земельного кадастру, є необхідними лише для оподаткування права користування земельною ділянкою, тоді як реєстр нерухомості, який ведеться нотаріусами, включає всі типи нерухомості (квартири, будинки, землі, комерційні приміщення та промислові будівлі) [3]. У Шотландії створення реєстрів також переслідує мету забезпечення принципу прозорості оподаткування власників земельних ділянок [8].

У Болгарії земельний кадастр містить інформацію про земельну нерухомість, незавершене будівництво, документи, які підтверджують права чи передачу у власність, зміну (припинення) права на нерухоме майно або викуп іпотеки на них. Ведення земельного кадастру в Болгарії, як і в Україні [9], покладено на агентство геодезії, картографії та кадастру [3].

Подібна система надання адміністративних послуг у сфері землекористування існує в Чеській Республіці, при цьому поряд 3 обліком земельних ділянок Управління з геодезії, картографії та кадастру веде державну реєстрацію фізичних осіб за їх постійним місцем проживання [10]. У Латвії в Державному кадастрі нерухомого майна містяться відомості про розташування власності, витяги із земельного кадастру, район будівель і споруд, реальну вартість майна, сервітути й обмеження, а також дані про законного власника чи користувача. Цей кадастр підпорядковується Державній земельній службі Латвії [3].

Лише в Литві ведення кадастру об'єктів нерухомості є прерогативою суб'єкта, що не $є$ органом державної влади, - Державного підприємства «Центр регістрів», яке $\epsilon$ товариством 3 обмеженою цивільною відповідальністю та зареєстроване на основі державної власності [11].

Данія так само обрала систему єдиного багатоцільового земельного кадастру, поєднаного 3 реєстром власності. Як і німецька система земельного кадастру, у Данії багатоцільовий земельний кадастр функціонує в цифровому форматі. Досить цікавим $є$ 
досвід підзвітності земельного реєстру органам судової влади, запроваджений у Данії, ФРН, Словенії [3].

Найбільш прозорою є система реєстрів нерухомого майна, речових прав, будівель і споруд, реєстру координат та адресного реєстру, що функціонує у Швеції та має назву «Шведський банк даних про нерухомість». Основна мета створення системи банку даних полягає в тому, що користувач має можливість отримати інформацію загального характеру про права й обтяження, пов'язані 3 конкретним об'єктом нерухомості. Характерною особливістю «Шведського банку даних про нерухомість» є граничний обсяг інформації, яка надходить до бази з інших реєстраційних систем від державних і місцевих органів. Тобто формування банку даних здійснюється значною кількістю органів у всій країні, що відповідають за ведення реєстрів у межах своєї юрисдикції. Громадськість повністю задоволена існуванням такої системи, адже для неї створена можливість доступу до інформаційних ресурсів, баз даних, які містять усю необхідну інформацію про об'єкти рухомого й нерухомого майна, іншу потрібну інформацію [1, с. 199].

Найвагомішим проектом міжнародного співробітництва в галузі систем реєстрації на сьогодні $\epsilon$ проект EULIS (European Land Information Service) [1]. У цьому проекті беруть участь Австрія, Швеція, Нідерланди, Англія та Уельс, Литва, Чехія, Ірландія, Шотландія, хоча анонсовано участь більшої кількості країн. До проекту EULIS приєдналася також Республіка Грузія [12], у якій віднині є відкритим доступ до реєстру нерухомого майна в країні. Зазначено, що до 1 січня 2017 р. інформація решти анонсованих країн-учасниць перебуватиме на стадії розробки та доопрацювання. Основне завдання проекту полягає в створенні системи ефективного доступного пошуку інформації через Інтернет у режимі онлайн за реєстраційними системами європейських країн.

Використання земельних ресурсів часто поєднується 3 отриманням права на спеціальне використання водних ресурсів.

У США державною структурою, яка є відповідальною за збирання, обробку, перевірку, узагальнення, надання екологічної інформації про стан водокористування, є Геологічна служба США. Дозволи на використання водних ресурсів також видаються цією службою [13]. Водночас у США роль державного регулювання відносин водокористування надзвичайно мінімізовано. Встановлюється принцип, що власник земельної ділянки має на власний розсуд використовувати підземні водні ресурси, також діє пріоритет використання берегових зон власниками прилеглих земельних ділянок. Протилежним є досвід правового регулювання використання водних ресурсів у ФРН. У цій країні всі види водних ресурсів, у тому числі підземні води, перебувають у власності держави, тому передання їх у приватну власність є неприпустимим. Водокористування допускається лише на підставі спеціальних дозволів, які видаються не 3 позиції економічних міркувань, а 3 огляду на принцип соціальних пріоритетів [14, с. 26].
За законодавством Республіки Білорусь існує єдиний перелік адміністративних процедур, що надаються за заявою громадян, затверджений Указом Президента Республіки Білорусь від 26 квітня 2010 p. № 200 [15]. У цьому указі визначено низку адміністративних процедур у сфері природокористування (глава 16). У сфері використання водних ресурсів у Республіці Білорусь визначено надання такої адміністративної послуги, як прийняття рішення про надання водних об'єктів (їх частин) у відокремлене водокористування 3 видачею спеціального державного акта (надається органами місцевого самоврядування на підставі поданих документів: заяви, плану місцезнаходження водного об'єкта, гідрологічних характеристик водного об'єкта (глибина, площа)) на безоплатній основі, при цьому рішення має бути прийняте впродовж 2 місяців із моменту подання документів на отримання дозволу.

Порівняно із законодавством України законодавством Республіки Білорусь передбачено розгалужену систему адміністративних процедур у сфері використання об'єктів тваринного світу як об'єктів полювання. Відповідно до Указу Президента Республіки Білорусь від 26 квітня 2010 р. № 200 [15] визначено такі адміністративні процедури у сфері використання об'єктів тваринного світу:

1) видачу дозволу на вилучення диких тварин iз їх звичайного середовища існування;

2) видачу свідоцтва про реєстрацію тварин, які перебувають у неволі, занесених до Червоної книги Республіки Білорусь;

3) видачу дозволу на вилучення диких тварин i дикорослих рослин, що належать до видів, занесених до Червоної книги Республіки Білорусь, із середовища їх існування та росту;

4) видачу дозволу на видалення об'єктів рослинного світу в населених пунктах;

5) видачу державного посвідчення на право полювання; трофеїв

6) видачу свідоцтва експерта 3 мисливських лювання;

7) обмін державного посвідчення на право по-

8) видачу дубліката державного посвідчення на право полювання замість втраченого (загубленого);

9) реєстрацію мисливських собак;

10) реєстрацію ловчих птахів, підсадних та інших диких тварин, які використовуються для полювання, натаскування й проведення змагань.

Удосконалення надання адміністративних послуг у сфері екології та природних ресурсів, як зазначає Ю. О. Легеза [16, с. 299-300], є необхідним через приведення здійснюваних дозвільних процедур, умов і порядку їх виконання у відповідність до вимог чинного законодавства; стандартизацію дозвільних процедур із впровадженням клієнтоорієнтованого підходу до надання дозвільних послуг; підвищення кваліфікації керівників і державних адміністраторів дозвільних центрів, посадових осіб дозвільних органів; покращення ресурсного забезпечення діяльності дозвільних центрів і дозвільних органів; підвищення рівня автоматиза- 
ції роботи з інформацією і запровадження електронного документообігу; впровадження єдиної системи моніторингу й оцінювання якості дозвільних послуг із залученням інституцій громадянського суспільства.

\section{5. Результати дослідження та їх обговорення}

Отже, на прикладі окремих зарубіжних країн можна пересвідчитись у тому, що кадастровореєстраційні системи надійно функціонують як у разі їх ведення одним конкретно-визначеним державним органом, так і в разі спільного ведення декількома органами в межах їхної компетенції. При цьому ефективність функціонування різних систем залежить винятково від правового механізму, визначеного державою. Це вимагає зосередження зусиль органів державної влади на побудові повноцінної нормативної бази для остаточного запровадження ефективної реєстраційної системи.

\section{6. Висновки}

На підставі комплексного аналізу наявних наукових та нормативних джерел висвітлено досвід зарубіжних країн 3 надання адміністративних послуг у сфері екології та природних ресурсів дозволило визна- чити такі напрями реформування публічного управління в Україні:

1) активізація впровадження конкурсного порядку укладення адміністративних договорів на геологічне вивчення надр та (або) видобування корисних копалин дозволяє уникнути суб'єктивного фактору при розподілі природних ресурсів загальнодержавного значення за умови дотримання принципів прозорості та відкритості проведення відповідних адміністративних процедур. Обгрунтовано доцільність впровадження досвіду Республіки Казахстан, що передбачає можливість застосування залежно від конкретних операцій з природокористування комбінованих договорів (контрактів), при цьому порядок укладання таких контрактів та їх зміст визначається законодавством;

2) створення централізованих реєстрів обліку природних ресурсів, в тому числі необхідність поєднання реєстрів земельних ділянок та об'єктів нерухомого майна

3) інформатизація реєстрів та забезпечення загальнодержавного доступу громадян до таких реєстрів, що можливо забезпечити лише в умовах державного централізованого підходу до організації їх ведення.

\section{Література}

1. Хохлова І. В., Шем’яков О. П. Виникнення права надрокористування: порівняльний аналіз законодавства країн СНД // Вісник Луганського державного університету внутрішніх справ імені Е. О. Дідоренка. 2010. № 1. С. 199-205.

2. Леонова О. В. Іноземний досвід правового регулювання адміністративних відносин у сфері надрокористування // Право і суспільство. 2013. № 2. С. 77-85.

3. Панас Р. М., Маланчук М. С. Порівняльна оцінка земельних кадастрів зарубіжних країн і України // Геодезія, картографія і аерофотознімання. 2008. № 70. С. 68-75.

4. О недрах и недропользовании: Закон Республики Казахстан 24.06.2010. URL: http://online.zakon.kz/Document/ ?doc_id=30770874\#pos=196;-294

5. Адміністративне право України: підручник / ред. Битяк Ю. П. Київ: Юрінком Інтер, 2005. 560 с.

6. Яремчук Р. Р. Міжнародно-правове регулювання співробітництва держав у сфері надрокористування // Корреспондент. 2012. № 12 (804). URL: https://blogs.korrespondent.net/blog/users/3333870-mizhnarodno-pravove-rehuluivanniaspivrobitnytstva-derzhav-u-sferi-nadrokorystuvannia

7. Конвенция о транснациональных корпорациях: международный документ от 6.03.1998. URL: http://zakon3.rada. gov.ua/laws/show/997_193

8. Land and buildings transaction tax // Registers of Scotland. URL: https://www.ros.gov.uk/services/land-and-buildingtransaction-tax

9. Деякі питання надання Державною службою з питань геодезії, картографії та кадастру та ії територіальними органами адміністративних послуг: Постанова Кабінету Міністрів України № 835. 1.07.2011 // Офіційний вісник України. 2011. № 59. Ст. 2374. C. 184. URL: http://zakon5.rada.gov.ua/laws/show/835-2011-\%D0\%BF

10. Statni sprava zememerictvi a katastru. URL: http://www.cuzk.cz

11. Nekilnojamojo turto registras. URL: http://www.registrucentras.lt/ntr/

12. Система електронних публічних послуг у Республіці Грузія. URL: http://www.napr.gov.ge/?lng=eng

13. Ottis L. E. Water Requirements of the Petroleum Refining Industry. Washington, 1963. URL: http://pubs.usgs.gov/wsp/ $1330 \mathrm{~g} /$ report.pdf

14. Социально-правовые механизмы природопользования (анализ концепций и подходов): аналит. обзор / Марков Ю. Г. и др. Новосибирск: Сибирское отделение РАН, 1995. 150 с.

15. Перечень административных процедур, осуществляемых государственными органами и иными организациями по заявлениям граждан: Указ Президента Республики Беларусь № 200. 26.04.2010. URL: http://pravo.by/ main.aspx?guid $=3871 \& \mathrm{p} 0=\mathrm{P} 31000200 \& \mathrm{p} 2=\{\mathrm{NRPA}\}$

16. Легеза Ю. О. Адміністративно-правові засади публічного управління у сфері використання природних ресурсів: дис. ... д-ра юрид. наук. Запоріжжя: ЗНУ, 2018. 512 с.

Рекомендовано до публікації д-р юрид. наук Легезою С.О. Дата надходження рукопису 15.05.2018

Кучма Костянтин Сергійович, кандидат юридичних наук, Дніпропетровський окружний адміністративний суд, вул. Академіка Янгеля, 4, м. Дніпро, Україна, 49089

E-mail: kuchma1911@gmail.com 